\begin{abstract}
Iranica
Abstracta Iranica Revue bibliographique pour le domaine irano-aryen

Volume 32-33 | 2013

Comptes rendus des publications de 2009-2010
\end{abstract}

\title{
Yuka Kadoi. Islamic Chinoiserie: The Art of Mongol Iran
}

\section{Vlad Atanasiu}

\section{(2) OpenEdition \\ 12 Journals}

\section{Electronic version}

URL: http://journals.openedition.org/abstractairanica/40797

DOI: 10.4000/abstractairanica.40797

ISSN: 1961-960X

Publisher:

CNRS (UMR 7528 Mondes iraniens et indiens), Éditions de l'IFRI

\section{Printed version}

Date of publication: 1 December 2013

ISSN: 0240-8910

\section{Electronic reference}

Vlad Atanasiu, « Yuka Kadoi. Islamic Chinoiserie: The Art of Mongol Iran », Abstracta Iranica [Online], Volume 32-33 | 2013, document 305, Online since 01 July 2016, connection on 26 September 2020. URL : http://journals.openedition.org/abstractairanica/40797; DOI : https://doi.org/10.4000/ abstractairanica. 40797

This text was automatically generated on 26 September 2020.

Tous droits réservés 


\title{
Yuka Kadoi. Islamic Chinoiserie: The Art of Mongol Iran
}

\author{
Vlad Atanasiu
}

\section{REFERENCES}

Yuka Kadoi. Islamic Chinoiserie: The Art of Mongol Iran. Edinburgh, Edinburgh University Press, 2009, 286 p.

1 East Asian influences have affected the development of Islamic arts owing, in particular, to intensified pan-Asian contacts during the rule of the Mongols and Timurids over Persia between the 13th and 15th centuries. Elements of the "Chinese" fashion (called Islamic Chinoiserie with reference to cultural fads in 19th-century Europe, such as the one for japonisme) are easily identifiable by amateurs of art and have been abundantly commented in scholarly publications. However an overview of the phenomenon has yet to be made. Thomas Allsen's work on Eurasian cultural exchanges, especially during the Pax Mongolica (Commodity and exchange in the Mongol Empire: A cultural history of Islamic textiles, Cambridge University Press, 2002, and Culture and conquest in Mongol Eurasia, Cambridge University Press, 2004), is a model for Islamic, Chinese and Mongol studies to build the (cultural, historical, religious, economic...) panorama that can explain Islamic Chinoiserie. Articles by Nancy Shatzman Steinhardt on the copy Chinese paintings by medieval central Asian artists are an excellent example of the minute inquires needed at the level of individual objects before any overview can be made. The multi-cultural education of researchers and a team approach are the keys to accessing sources originating in eastern and western Asia.

2 Islamic Chinoiserie seeks "to furnish a sound art-historical analysis of Chinese elements in Iranian art under the Mongols, and to give a hitherto unknown insight into this phenomenon". Yuka Kadoi, now at the Art Institute of Chicago, has accomplished this work due to her double background in Chinese and Islamic studies. 
This compendium identifies a number of Chinese artistic imports, provides information about their cultural significance in source and target societies, traces their transmission channels, and shows their degree of transformation during the acculturation process. Focus is on human beings and their artifacts (face shapes, dress peculiarities, ceremonies, architecture...), animals (mostly imaginary: dragons and "unicorns", Simurgh and phoenix birds, ducks, horses...) and landscape (rocks, clouds, water, trees, lotus, grass...) - more on the stylistic than technical aspects of the production of art objects. The chaptering of the book has, however, been influenced by the technical aspects, for example imports of ceramic-making techniques before the Mongols, followed by imports of ceramics motifs during the Mongol period. In effect, the book is organized by the material used for artworks: textiles (chapter 1), ceramics (chapter 2), metal, glass, wood, lacquer, stone (chapter 3), book paintings (chapters 4 to 6). Sections are also devoted to objects selected by functionality or origin, such as mirrors or the metalwork of the Golden Horde. Book paintings are the major section in this volume, with a focus on pre-1340 Ilkhanid examples from northwestern Iran and on regional manuscripts. An entire chapter is devoted to the various editions of Rašìd al-Dīn's Jāmi' al-Tawārì̈, including the historical curiosities of the "Diez Albums".

Classifying objects by the material used to make them is practical for managing art collections, since it facilitates packaging, transportation, storage, restoration and exhibition. It also provides a sense of consistency and value. From a cultural point of view however, this museological approach tends to strip objects of their context, an effect that is counterproductive for explaining Islamic Chinoiserie motifs which were mostly independent of the medium. Dragons, lotuses, clouds and suchlike were transferred via drawings on paper, as the author rightly points out, to stone, wood, ceramics, leather book bindings or any other suitable material. A presentation by theme rather than material or a presentation of individual objects would have spared the author repetitions and turned the book into a handy catalog of Chinese elements in Mongol Islamic art.

With due deference to the time spent by the author preparing her book (A dozen illustrations are meticulously reproduced from hand-drawings, and others have probably necessitated travels under heroic conditions), this reviewer would also like to suggest that the publisher reconsider some of the material aspects of this book: the surface of the paper used is so shiny that the reader has to constantly move the book to locate the right reading angle, the font is too light and has serifs too pointed for glossy paper, and the layout has been done on the fly. The book merits the exquisite craftsmanship found in the first edition (1967, not the second in 2004!) of C.E. Bosworth's The Islamic dynasties. 


\section{AUTHORS}

\section{VLAD ATANASIU}

Paris 